\title{
Dickeya zeae strains isolated from rice, banana and clivia rot plants show great virulence differentials
}

\author{
Ming $\mathrm{Hu}^{1,2}$, Jieling $\mathrm{Li}^{1,2}$, Ruiting Chen ${ }^{1,2}$, Wenjun $\mathrm{Li}^{1,2}$, Luwen Feng ${ }^{1,2}$, Lei Shi ${ }^{1,2}$, Yang Xue ${ }^{1,2}$, Xiaoyin Feng ${ }^{1,2}$,
} Lianhui Zhang ${ }^{1,2^{*}}$ and Jianuan Zhou ${ }^{1,2^{*}}$ (i)

\begin{abstract}
Background: Dickeya zeae is the causal agent of maize and rice foot rot diseases, but recently it was also found to infect banana and cause severe losses in China. Strains from different sources showed significant diversity in nature, implying complicated evolution history and pathogenic mechanisms.

Results: D. zeae strains were isolated from soft rot banana plants and ornamental monocotyledonous Clivia miniata. Compared with $D$. zeae strain EC1 isolated from rice, clivia isolates did not show any antimicrobial activity, produced less extracellular enzymes, had a much narrow host ranges, but released higher amount of extracellular polysaccharides (EPS). In contrast, the banana isolates in general produced more extracellular enzymes and EPS than strain EC1. Furthermore, we provided evidence that the banana D. zeae isolate MS2 produces a new antibiotic/ phytotoxin(s), which differs from the zeamine toxins produced by rice pathogen D. zeae strain EC1 genetically and in its antimicrobial potency.

Conclusions: The findings from this study expanded the natural host range of $D$. zeae and highlighted the genetic and phenotypic divergence of $D$. zeae strains. Conclusions can be drawn from a series of tests that at least two types of $D$. zeae strains could cause the soft rot disease of banana, with one producing antimicrobial compound while the other producing none, and the D. zeae clivia strains could only infect monocot hosts. D. zeae strains isolated from different sources have diverse virulence characteristics.
\end{abstract}

Keywords: Dickeya zeae, Virulence factor, Pathogenicity, Host range

\section{Background}

Dickeya species (spp.), is one of the top ten important bacterial phytopathogens in the world, and has been listed as a plant quarantine pest in China since 2007 [1, 2]. There are currently 8 species in this genus, including $D$. dianthicola, $D$. dadantii, $D$. zeae, $D$. chrysanthemi, $D$. paradisiaca, $D$. solani, $D$. aquatic and $D$. fangzhongdai [3-6], and among them, D. dadantii, D. zeae and D. solani usually cause devastating disease, resulting in a considerable loss in crop yield, especially on potato, rice and banana [7-12].

\footnotetext{
* Correspondence: Ihzhang01@scau.edu.cn; jianuanzhou@scau.edu.cn 'Integrative Microbiology Research Centre, South China Agricultural University, Guangzhou 510642, China

Full list of author information is available at the end of the article
}

Being located in a divergent evolutionary branch, D. zeae bacteria were reported to infect a wide range of plants all over the world, including 4 kinds of natural dicotyledonous hosts such as potato, tobacco, Chrysanthemum and Philodendron, and 6 kinds of natural monocotyledonous hosts such as maize, rice, banana, pineapple, Brachiaria and hyacinth (Additional file 1) [3, 8, 10, 12-32], besides, other 32 kinds of plants were reported as artificial hosts of $D$. zeae (Additional file 1) [13, 33, 34].

Latent infection appears to be a common trait of $D$. $z e a e$. For instance, rice foot rot disease occurred severely in Jiangsu Province in 1980s resulting in about 90\% losses on rice yield [35], but inactive for about 10 years till in 2000s, outbreak occurred in Fujian, Hunan, Guizhou, and Shandong provinces with different disease incidences ranging from 15 to $100 \%$ [36-38]. The disease

(c) The Author(s). 2018 Open Access This article is distributed under the terms of the Creative Commons Attribution 4.0 International License (http://creativecommons.org/licenses/by/4.0/), which permits unrestricted use, distribution, and reproduction in any medium, provided you give appropriate credit to the original author(s) and the source, provide a link to the Creative Commons license, and indicate if changes were made. The Creative Commons Public Domain Dedication waiver (http://creativecommons.org/publicdomain/zero/1.0/) applies to the data made available in this article, unless otherwise stated. 
currently occurs in Guangdong Province occasionally and sporadically. However, banana soft rot disease also caused by $D$. zeae has become a severe problem in Guangdong Province since 2009, with over 6000 ha of banana plantation being infected from 2010 to 2012 [10, 12]. The disease is now spreading to the major banana plantation fields in China in Provinces of Fujian, Yunnan, Hainan and Guangxi. Study on D. zeae banana strain is rare and its pathogenicity mechanisms are unclear.

Among the Dickeya spp., D. dadantii is perhaps the most characterized representative. The pathogen produces a range of virulence factors including cell wall degrading enzymes, type III secretion system (T3SS), siderphores, and indigoidine pigment, which collectively contribute to bacterial virulence [39-42]. Different from other Dickeya species, D. zeae can infect both dicots and monocots [7], indicating the existence of additional virulence factors. Genetic analysis and genome sequence comparison identified a $z m s$ gene cluster in $D$. zeae rice strains, which encodes the biosynthesis of zeamine phytotoxins capable of inhibiting rice seeds germination and growth $[11,43,44]$. Characterization of the $D$. zeae rice isolate $\mathrm{EC} 1$ also unveiled a quorum sensing (QS) system that produces and senses acyl homoserine lactone (AHL) signal to regulate expression of virulence associated genes, as well as a MarR family transcriptional regulator SlyA, and hereafter, to influence cell motility and biofilm formation [7, 44]. In addition, strain EC1 also relies on a Fis transcriptional regulator to directly regulate the expression of $z m s$ genes and production of cell wall degrading enzymes [45]. However, many detailed virulence regulatory mechanisms of $D$. zeae still remain unknown, especially in the banana strains, and few virulence factors related to host specificity have been determined.

In this study, $D$. zeae strains from rice, banana and monocot ornamental clivia plants that respectively cause severe bacterial rot disease in fields were collected to explore their phylogenetic relationship, and virulence differentials among strains were investigated by comparing the production of major virulence factors including extracellular enzymes, extracellular polysaccharides (EPS) and phytotoxins, nematode-killing activity and pathogenicity on many reported host plants. The findings from this study may present a new insight and clues for the control of bacterial soft rot diseases on crops.

\section{Results}

\section{Strains isolated from soft rot banana and clivia plants} were classified as $D$. zeae based on phylogenetic analysis

$D$. zeae was reported to be the causal agent of banana soft rot disease in Guangzhou, China [10, 12]. In this study, strains MS2 and MS3 that caused severe soft rot disease were respectively isolated from the basal pseudostems of banana plants in Nansha and Panyu Districts in Guangzhou city in 2012; and strains JZL1, JZL2 and
JZL7 were isolated from the decayed centre leaves of clivia plants collected at Fangcun flower market in Guangzhou in 2017. The pure cultures of these isolates were inoculated to the corresponding banana and clivia plants, and typical soft rot symptoms were noticed (data not shown), validating their roles as banana and clivia pathogens, respectively. To identify the taxonomic status of these pathogens, MLSA analysis was performed based on the partial sequences of $16 S$ rRNA gene, and the other four housekeeping genes including $a t p D, \operatorname{gyr} B$, infB and $r p o B$. Results showed that the three JZL strains contain identical housekeeping gene sequences, thus were designated as strain JZL. The alignment results showed that strains JZL, MS2 and MS3 clustered in the same branch with known $D$. zeae strains both in the $16 S$ rDNA tree (Fig. 1) and the joint phylogenetic tree built on the concatenated nucleotide sequences of atpD, gyrB, infB and rpoB from 30 Dickeya species and strains (Fig. 2).

The 16S rDNA sequences of strains MS2 and MS3 are fully identical to those of D. zeae MS1 (from banana) [12], 99\% identical to those of D. zeae rice isolates EC1 [11, 43], ZJU1202 [19] and DZ2Q [20]. Strains MS2 and MS3 had the identical atpD and $g y r B$ sequences, showing $99 \%$ identity to their counterparts of strain MS1. In contrast, while strains MS3 and MS1 contain the same infB and rpoB gene sequences, strain MS2 shared 99\% identity to those of strain MS1. Cumulatively, these data indicate that strains MS2 and MS3 are members of D. zeae, closely related to the previously identified D. zeae strain MS1 [12].

The $16 S$ rDNA sequence of strain JZL is $99 \%$ identical to those of D. zeae strains EC1, Ech586 (from Philodendron) and MK19 (from river water), and 98\% identical to that of strain MS2. The assembled sequence of $a t p D, \operatorname{gyr} B$, $\operatorname{infB}$ and rpoB (3429 bp) of MS2 is $99 \%$ identical to those of strains MS1 and MS3, 98\% identical to that of strain EC1, and 97\% identical to that of strain Ech586; and the assembled sequence of strain JZL is $97 \%$ identical to those of strains EC1 and Ech586, and 98\% identical to those of strains MS1, MS2, MS3 and MK19. In summary, these data establish that strain JZL also belongs to the species D. zeae. To our knowledge, this is the first report indicating clivia as another natural host plant of $D$. zeae. Thereafter, the natural host range of $D$. zeae is expanded.

\section{D. zeae strains in Asian countries were usually isolated from monocots}

D. zeae was reported to infect both monocots and dicots $[7,11]$. In most cases, it was isolated from monocot natural hosts, such as maize, rice, banana, pineapple, Brachiaria and hyacinth [3, 10, 13, 14, 16, 18, 21, 23-26]. By analysing the distribution of D. zeae, we found that it was most geographically originated from southeast Asian countries, especially the southeast of China, on rice, maize and banana (Additional files 1 and 2). Apart from China, D. zeae was 


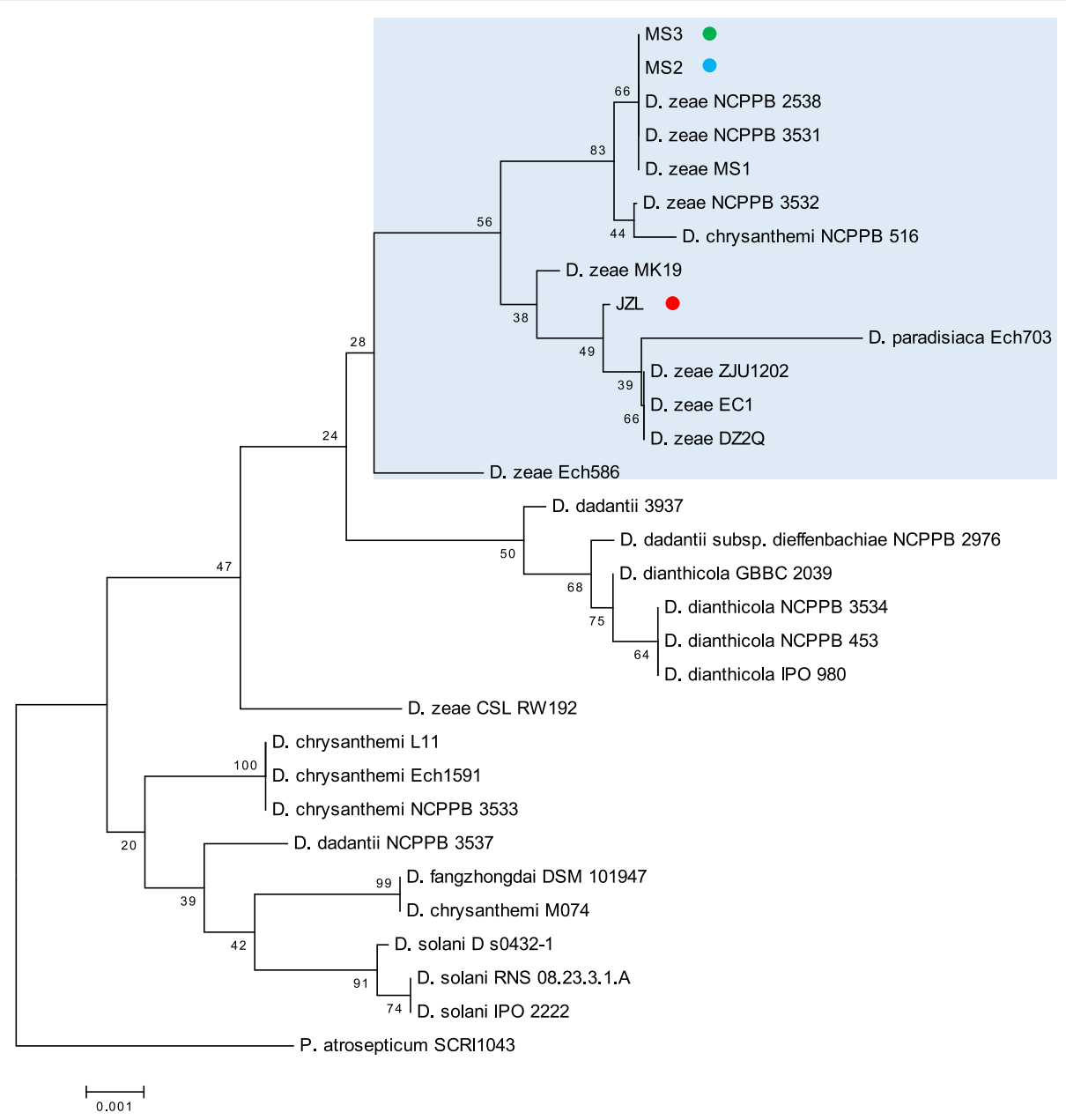

Fig. 1 Phylogenetic tree based on the 165 rRNA sequences of Dickeya species. Consensus sequences were aligned with ClustalW and trimmed in size of 654 bp. Bootstrap value after 1000 replicates is expressed as percentages. Pectobacterium atrosepticum SCRI 1043 is included as an outgroup. Bar, $0.1 \%$ substitution rate per site

also isolated from Japan, South Korea, North Korea, Philippines, India, Indonesia and Bangladesh on rice plants, and from South Korea, Japan, Thailand and India on maize host. It was currently only found in China on banana host, and in Malaysia on pineapple (Additional file 2). Given that pineapple heart rot disease was also found in Philippines and Hawaii, the pathogen was probably a novel species different from $D$. zeae [21, 27]. These geographical distribution and natural host range findings suggest that $D$. zeae may have a high level of host specificity and geographic related evolution history.

\section{D. zeae strain JZL showed a significantly narrower host range than other $D$. zeae strains}

To evaluate the host ranges of the $D$. zeae isolates, we performed pathogenicity tests on various reported hosts of $D$. zeae. Results showed that strains MS2 and MS3 could infect all the tested host plants similar to strain EC1, while JZL strains could not infect dicotyledonous plants including
Cucumis sativus, Benincasa hispida, Brassica pekinensis, Raphanus sativus, Daucus carota, Solanum tuberosm, Lycopersicon esculentum, Solanum melongena and Capsicum annuum, but infect monocots including Oryza sativa, Musa sapientum, Clivia miniata, Zingiber officinale, Gladiolus gandavensis, Colocasia esculenta and Alocasia macrorrhiza (Table 1, Additional file 3), suggesting a significantly narrower host range than the other strains isolated from rice (strain EC1) and banana (strains MS2 and MS3). In addition, the soft rot symptoms on monocots caused by strains JZLs developed more slowly than those caused by the others except on clivia, and strains JZLs could not infect onion (Allium cepa) (Table 1, Additional file 3).

D. zeae clivia strains showed weak aggressiveness on potato and cabbage, but were comparable with rice and banana strains on banana and clivia

To understand whether the decreased virulence of $D$. zeae clivia strains on hosts was due to their weak aggressiveness, 


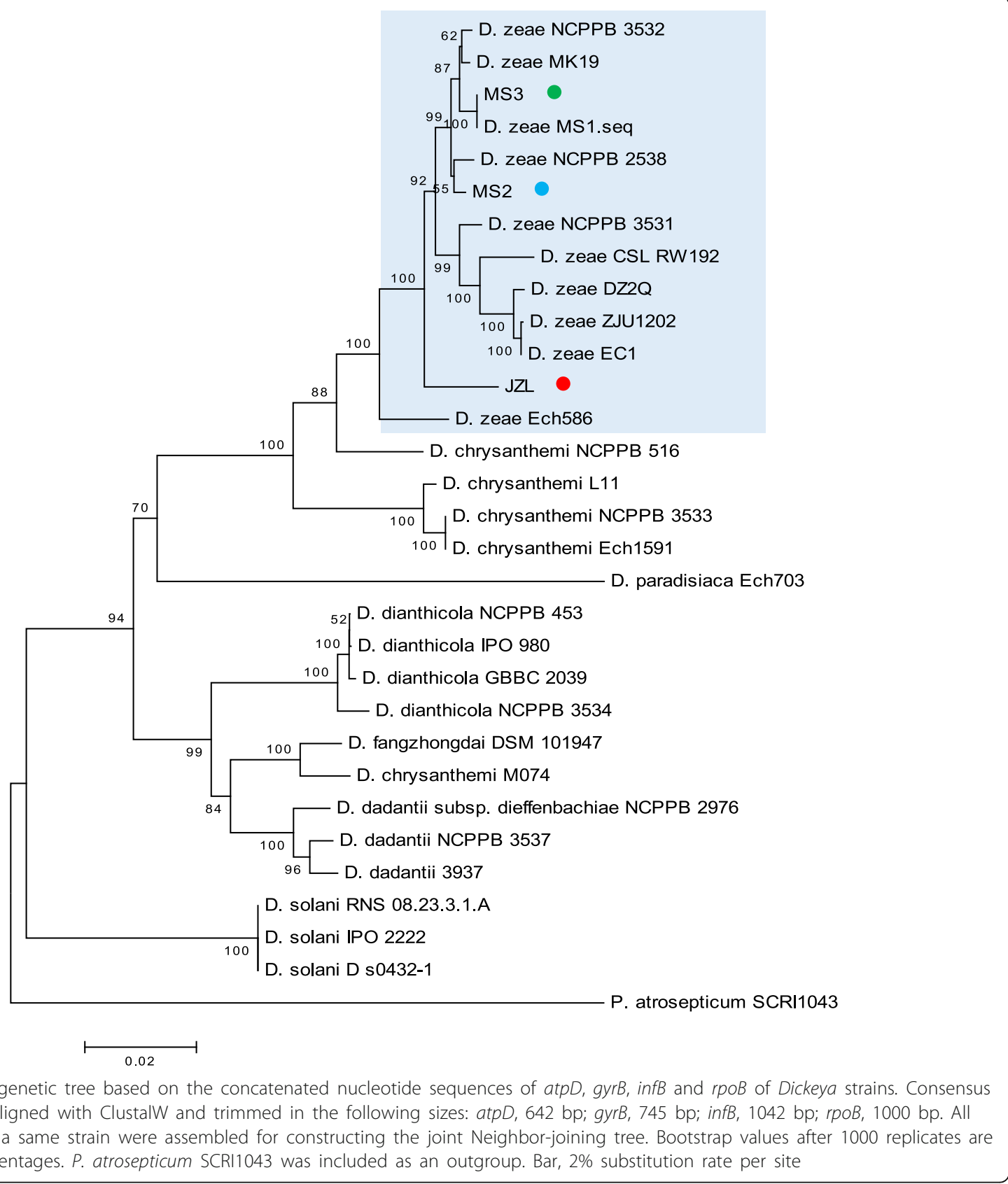

we performed pathogenicity tests on two dicotyledonous and two monocotyledonous plants in equal weight, and calculated the numbers of bacterial cells invading into the plant tissues. Results showed that the JZL strains could not propagate in potato or cabbage tissues after inoculation for $12 \mathrm{~h}$ and $24 \mathrm{~h}$, while EC1, MS2 and MS3 strains grew rapidly in potato in $12 \mathrm{~h}$, and slowly in cabbage (Fig. 3a and b). In banana tissues, the cell number of all the strains were similar no matter at $12 \mathrm{~h}$ or $24 \mathrm{~h}$ post inoculation (Fig. 3c). In clivia, JZL strains initially grew slower than strains EC1, MS2 and MS3, but caught up at $24 \mathrm{~h}$ post inoculation (Fig. 3d).
D. zeae strains from clivia and banana differ in production of extracellular enzymes and polysaccharides

From the above results of pathogenicity tests, we inferred that the narrower host range of JZL strains may be due to its less virulence than the other strains, and strains EC1, MS2 and MS3 probably possess some additional virulence factor(s) than the three JZL strains. To compare the major virulence factors produced by different $D$. zeae strains, we first measured their growth dynamic process. Results showed that all the strains shared a similar growth pattern reaching the peak from $12 \mathrm{~h}$ to $16 \mathrm{~h}$ both in LB and LS5 media, though the cell density of JZL strains could not 
Table 1 Pathogenicity tests of D. zeae strains on some dicotyledonous and monocotyledonous plants

\begin{tabular}{|c|c|c|c|c|c|c|c|c|c|}
\hline \multicolumn{3}{|c|}{ Inoculated plant } & \multirow{2}{*}{$\begin{array}{l}\text { Inoculation } \\
\text { amount, } \\
\text { time }\end{array}$} & \multicolumn{6}{|c|}{ Diseased area $\left(\mathrm{mm}^{2}\right)$} \\
\hline Class & Species & Organ & & $\mathrm{EC} 1$ & MS2 & MS3 & JZL1 & JZL2 & JLZ7 \\
\hline \multirow[t]{9}{*}{ Dicots } & $\begin{array}{l}\text { Cucumis } \\
\text { sativus }\end{array}$ & Fruit & $2 \mu \mathrm{L}, 24 \mathrm{~h}$ & $57.22 \pm 7.70$ & $107.97 \pm 42.00$ & $65.46 \pm 7.88$ & 0 & 0 & 0 \\
\hline & $\begin{array}{l}\text { Benincasa } \\
\text { hispida }\end{array}$ & Fruit & $2 \mu \mathrm{L}, 24 \mathrm{~h}$ & $1140.57 \pm 15.55$ & $1336.50 \pm 3.32$ & $1252.61 \pm 18.71$ & 0 & 0 & 0 \\
\hline & $\begin{array}{l}\text { Brassica } \\
\text { pekinensis }\end{array}$ & Petiole & $2 \mu \mathrm{L}, 12 \mathrm{~h}$ & $56.81 \pm 3.14$ & $49.83 \pm 2.73$ & $42.40 \pm 3.17$ & 0 & 0 & 0 \\
\hline & $\begin{array}{l}\text { Raphanus } \\
\text { sativus }\end{array}$ & Tuber & $2 \mu \mathrm{L}, 24 \mathrm{~h}$ & $156.89 \pm 2.60$ & $106.72 \pm 2.03$ & $99.84 \pm 9.76$ & 0 & 0 & 0 \\
\hline & $\begin{array}{l}\text { Daucus } \\
\text { carota }\end{array}$ & Tuber & $2 \mu \mathrm{L}, 24 \mathrm{~h}$ & $274.83 \pm 18.74$ & $266.70 \pm 8.98$ & $231.42 \pm 14.11$ & 0 & 0 & 0 \\
\hline & $\begin{array}{l}\text { Solanum } \\
\text { tuberosm }\end{array}$ & Tuber & $2 \mu \mathrm{L}, 24 \mathrm{~h}$ & $173.33 \pm 4.28$ & $211.05 \pm 20.54$ & $171.45 \pm 6.07$ & 0 & 0 & 0 \\
\hline & $\begin{array}{l}\text { Lycopersicon } \\
\text { esculentum }\end{array}$ & Fruit & $100 \mu \mathrm{L}, 2 \mathrm{~d}$ & $908.22 \pm 5.95$ & $904.75 \pm 9.80$ & $945.81 \pm 13.77$ & 0 & 0 & 0 \\
\hline & $\begin{array}{l}\text { Solanum } \\
\text { melongena }\end{array}$ & Fruit & $100 \mu \mathrm{L}, 2 \mathrm{~d}$ & $66.52 \pm 2.95$ & $61.83 \pm 1.67$ & $86.72 \pm 0.85$ & 0 & 0 & 0 \\
\hline & $\begin{array}{l}\text { Capsicum } \\
\text { annuum }\end{array}$ & Fruit & $2 \mu \mathrm{L}, 24 \mathrm{~h}$ & $101.79 \pm 8.81$ & $106.65 \pm 10.76$ & $191.42 \pm 10.55$ & 0 & 0 & 0 \\
\hline \multirow[t]{8}{*}{ Monocots } & $\begin{array}{l}\text { Oryza } \\
\text { sativa }\end{array}$ & Stem & $200 \mu \mathrm{L}, 7 \mathrm{~d}$ & $720.62 \pm 21.48$ & $575.71 \pm 29.53$ & $539.35 \pm 17.77$ & $\begin{array}{l}452.67 \pm \\
19.53\end{array}$ & $\begin{array}{l}413.01 \pm \\
12.64\end{array}$ & $\begin{array}{l}499.85 \pm \\
12.09\end{array}$ \\
\hline & $\begin{array}{l}\text { Musa } \\
\text { sapientum }\end{array}$ & Stem & $200 \mu \mathrm{L}, 7 \mathrm{~d}$ & $1110.83 \pm 19.23$ & $1358.89 \pm 17.78$ & $1201.88 \pm 19.91$ & $\begin{array}{l}407.90 \pm \\
12.48\end{array}$ & $\begin{array}{l}377.89 \pm \\
13.71\end{array}$ & $\begin{array}{l}464.23 \pm \\
11.06\end{array}$ \\
\hline & $\begin{array}{l}\text { Clivia } \\
\text { miniata }\end{array}$ & Leaf & $200 \mu \mathrm{L}, 24 \mathrm{~h}$ & $1643.86 \pm 6.94$ & $2195.85 \pm 7.06$ & $1239.95 \pm 7.55$ & $\begin{array}{l}1807.41 \pm \\
9.52\end{array}$ & $\begin{array}{l}1693.21 \pm \\
20.27\end{array}$ & $\begin{array}{l}1594.90 \pm \\
14.66\end{array}$ \\
\hline & $\begin{array}{l}\text { Allium } \\
\text { cepa }\end{array}$ & Bulb & $2 \mu \mathrm{L}, 24 \mathrm{~h}$ & $185.83 \pm 21.68$ & $194.27 \pm 18.73$ & $119.90 \pm 11.29$ & 0 & 0 & 0 \\
\hline & $\begin{array}{l}\text { Zingiber } \\
\text { officinale }\end{array}$ & Tuber & $2 \mu \mathrm{L}, 24 \mathrm{~h}$ & $134.37 \pm 14.17$ & $86.92 \pm 6.75$ & $87.31 \pm 12.23$ & $47.44 \pm 7.16$ & $\begin{array}{l}65.81 \pm \\
6.11\end{array}$ & $\begin{array}{l}81.33 \pm \\
13.96\end{array}$ \\
\hline & $\begin{array}{l}\text { Gladiolus } \\
\text { gandavensis }\end{array}$ & Stem & $200 \mu \mathrm{L}, 7 \mathrm{~d}$ & $254.16 \pm 9.05$ & $168.17 \pm 9.23$ & $171.59 \pm 5.92$ & $36.75 \pm 1.62$ & $\begin{array}{l}36.38 \pm \\
2.39\end{array}$ & $\begin{array}{l}36.85 \pm \\
3.05\end{array}$ \\
\hline & $\begin{array}{l}\text { Colocasia } \\
\text { esculenta }\end{array}$ & Tuber & $2 \mu \mathrm{L}, 5 \mathrm{~d}$ & $461.847 \pm 15.55$ & $247.31 \pm 15.31$ & $117.34 \pm 8.00$ & $81.83 \pm 6.00$ & $\begin{array}{l}40.46 \pm \\
5.54\end{array}$ & $\begin{array}{l}79.48 \pm \\
3.91\end{array}$ \\
\hline & $\begin{array}{l}\text { Alocasia } \\
\text { macrorrhiza }\end{array}$ & Stem & $200 \mu \mathrm{L}, 7 \mathrm{~d}$ & $2860.90 \pm 65.15$ & $2763.17 \pm 30.46$ & $2633.75 \pm 35.94$ & $1316.86 \pm 17.97$ & $\begin{array}{l}1430.45 \pm \\
32.58\end{array}$ & $\begin{array}{l}1381.58 \pm \\
15.23\end{array}$ \\
\hline
\end{tabular}

reach $\mathrm{OD}_{600}=1.3$ in LS5 medium (Fig. 4a). We then measured the production of cell wall degrading enzymes and extracellular polysaccharides (EPS), which are two categories of virulence factors produced by the rice pathogen $D$. zeae strain EC1 $[44,59]$. Results showed that JZL strains produced lower amount of pectate lyases (Pel), polygalacturonases (Peh), proteases (Prt) and cellulases (Cel) than the others, especially hardly any protein degrading zone was visible. In contrast, the two banana strains, MS2 and MS3, produced higher amounts of the above-mentioned extracellular enzymes than those produced by the rice strain EC1 except polygalacturonases (Fig. 4b). In a somewhat different pattern to the production of cell wall degradation enzymes, the rice pathogen strain EC1 produced significantly less EPS than the MS strains from banana and the JZL strains from clivia plants (Fig. 4c).
D. zeae banana strain MS2 produces novel antibiotic-like toxin(s) different from zeamines with slightly weaker ability to inhibit rice seed germination and kill nematodes Our previous study found that D. zeae rice strain EC1 produces zeamines as major virulence factors in both rice plants and potato tubers $[11,60]$. The phytotoxins are encoded by a $z m s$ gene cluster only found in $D$. zeae rice strains including ZJU1202 [19] and DZ2Q [20], some D. solani and Serratia plymuthica strains [43, 61], but were absent in other $D$. zeae strains isolated from other hosts including strain MS1 from banana [12, 43]. The results from this study showed that JZL strains could not produce zeamines, neither could strain MS3 (Fig. 4d), consistent with our previous findings [43].

Surprisingly, strain MS2 produced an antibiotic-like toxin(s) to inhibit the growth of $E$. coli $\mathrm{DH} 5 \alpha$, resulting 

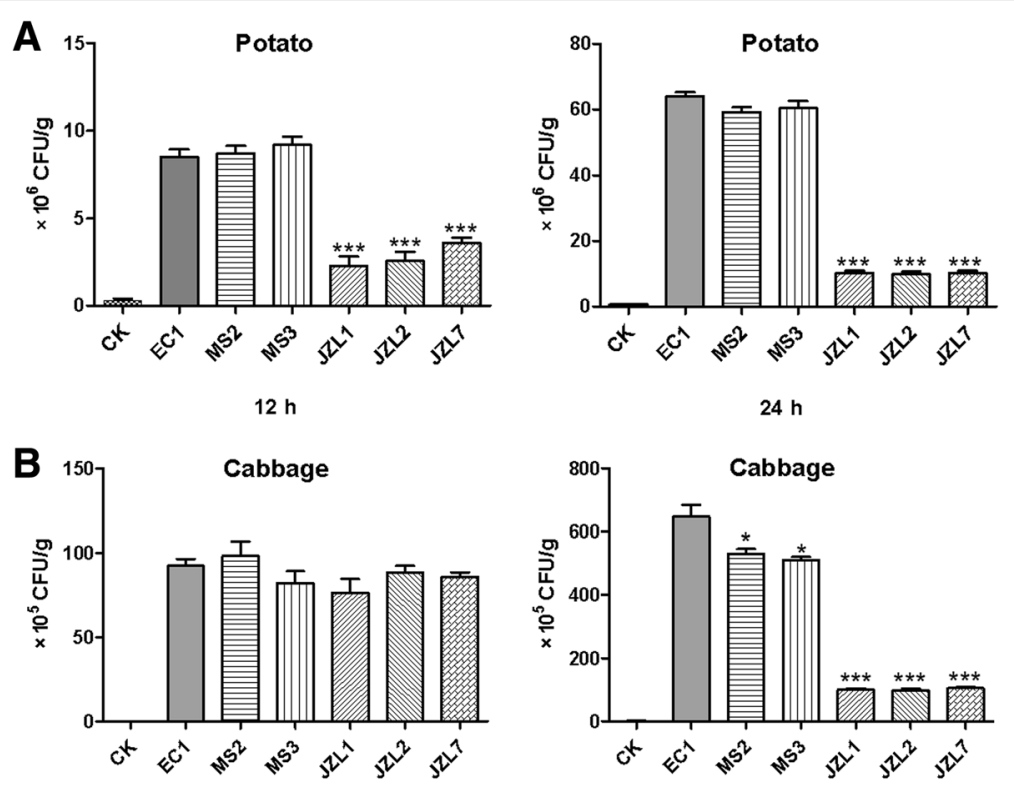

$24 \mathrm{~h}$

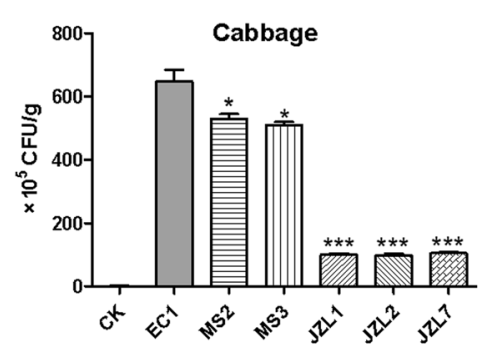

$12 \mathrm{~h}$

$24 \mathrm{~h}$
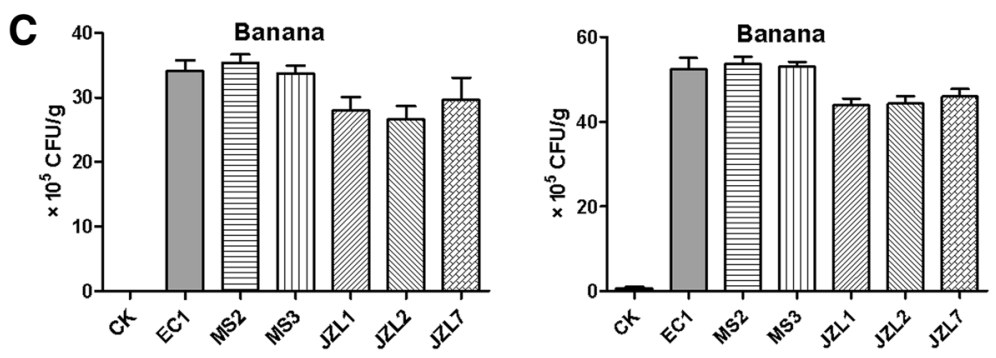

$12 \mathrm{~h}$

$24 \mathrm{~h}$

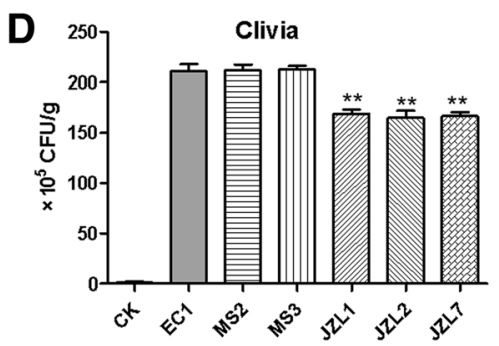

$12 \mathrm{~h}$

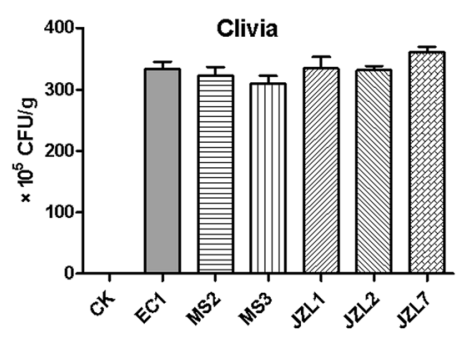

$24 \mathrm{~h}$

Fig. 3 The number of bacterial cells of all the tested D. zeae strains invading into potato (a), cabbage (b), banana (c) and clivia (d), respectively. Healthy plant materials were surface-sterilized and inoculated with $2 \mu \mathrm{L}$ of bacterial overnight cultures $\left(\mathrm{OD}_{600}=2.0\right)$ in $\mathrm{LB}_{\mathrm{B}}$ medium, and incubated at $28^{\circ} \mathrm{C}$. Tissues were taken out after $12 \mathrm{~h}$ and $24 \mathrm{~h}$, respectively. And the diseased and surrounding healthy tissues in equal weight were cut and ground, and then added with $10 \mathrm{~mL}$ of sterilized $0.85 \% \mathrm{NaCl}$ solution, stirred evenly, and $1 \mathrm{~mL}$ of which was diluted in series gradients, and $100 \mu \mathrm{L}$ in each gradient was spread evenly onto LB agar plates in triplicates and kept at $28^{\circ} \mathrm{C}$ for 24 h. Colonies between 30 to 300 CFU were counted. LB medium was used as a negative control. Each assay was repeated three times with duplicates

in a halo with a vague edge, quite different from the halo with a clear edge caused by strain EC1 (Fig. 5a). Given that zeamines are able to inhibit rice seed germination, we tested the inhibitory activity of strain MS2 against rice seeds. The results indicated that strain MS2 had a moderate inhibitory effect on seed germination, with an inhibitory rate being about $50 \%$, less than that of $87 \%$ by strain EC1 (Fig. 5b). Consistent with its negative antimicrobial activity phenotype (Fig. 3d, Fig. 5a), strain MS3 had no effect on seed germination (Fig. 5b). It is inferred that the inhibitory activity against seed germination is probably due to the toxin(s) produced by strain MS2, which is supposed to be a kind of extracellular nonprotein metabolite since it did not loss the activity 

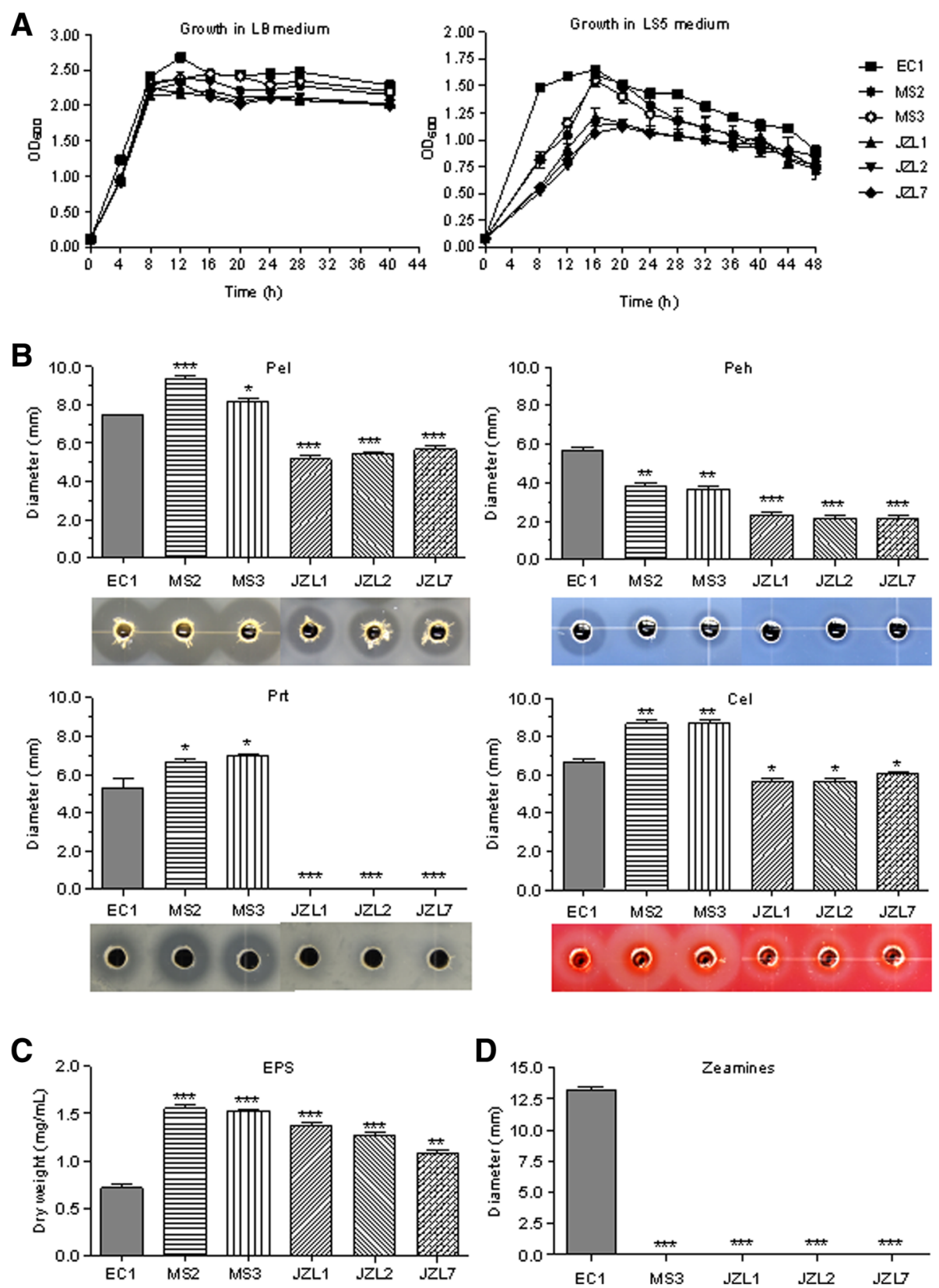

Fig. 4 Major virulence factors produced by D. zeae strains. a Growth curves of D. zeae strains in LB and LS5 media. b Extracellular cell wall degrading enzymes produced by $D$. zeae strains. Samples of $40 \mu \mathrm{L}$ bacterial cells $\left(\mathrm{OD}_{600}=1.8\right)$ were added to the assay plate wells ( $4 \mathrm{~mm}$ in diameter) and incubated at $28^{\circ} \mathrm{C}$. Pel and Peh assay plates were treated with $4 \mathrm{~N} \mathrm{HCl}$ after $11 \mathrm{~h}$ and $14 \mathrm{~h}$ respectively. Cel assay plate was stained with $0.1 \%(\mathrm{~W} / \mathrm{v})$ Congo Red for $15 \mathrm{~min}$ after $14 \mathrm{~h}$, and decolored with $1 \mathrm{M} \mathrm{NaCl}$ twice. Prt assay plate was taken photos after $24 \mathrm{~h}$ without any further treatment. c Production of extracellular polysaccharides of $D$. zeae strains. Samples of $3 \mathrm{~mL}$ bacterial cultures $\left(\mathrm{OD}_{600}=1.8\right)$ were applied into $300 \mathrm{~mL} \mathrm{LB}$ medium and grown with shaking at $200 \mathrm{r} / \mathrm{m}$ for $12 \mathrm{~h}$, which were centrifuged at $8000 \mathrm{rpm}$ for $40 \mathrm{~m}$, and then at $4000 \mathrm{rpm}$ for $20 \mathrm{~m}$ to obtain $250 \mathrm{~mL}$ supernatants. Double volumes of absolute ethanol were added to the supernatants, mixed thoroughly, stored at $4{ }^{\circ} \mathrm{C}$ overnight for precipitation, and centrifuged at $8000 \mathrm{rpm}$ for $40 \mathrm{~m}$. Finally, supernatants were discarded and pellets were weighed after drying at $55^{\circ} \mathrm{C}$ overnight. $\mathbf{d}$ Phytotoxins produced by D. zeae strains. The bioassay plate was prepared as previously described [44]. Samples of $20 \mu \mathrm{L}$ of bacterial cultures $\left(\mathrm{OD}_{600}=1.5 \mathrm{in} \mathrm{LS5}\right.$ medium) were added into the toxin bioassay plate wells ( $4 \mathrm{~mm}$ in diameter), and incubated overnight at $37^{\circ} \mathrm{C}$

after boiling at $100{ }^{\circ} \mathrm{C}$ for 10 min or treating with Protease $\mathrm{K}$ at $37^{\circ} \mathrm{C}$ for $30 \mathrm{~min}$ (Fig. 5c).

To define whether the phytotoxin(s) produced by strain MS2 are zeamines or derivatives, we detected the zeamine biosynthesis genes from $z m s O$ to $z m s N$ based on their DNA sequences in strain EC1 [43], and results showed that no corresponding bands could be amplified if using the genomic DNA of strain MS2 or MS3 as a template (Fig. 5d). 


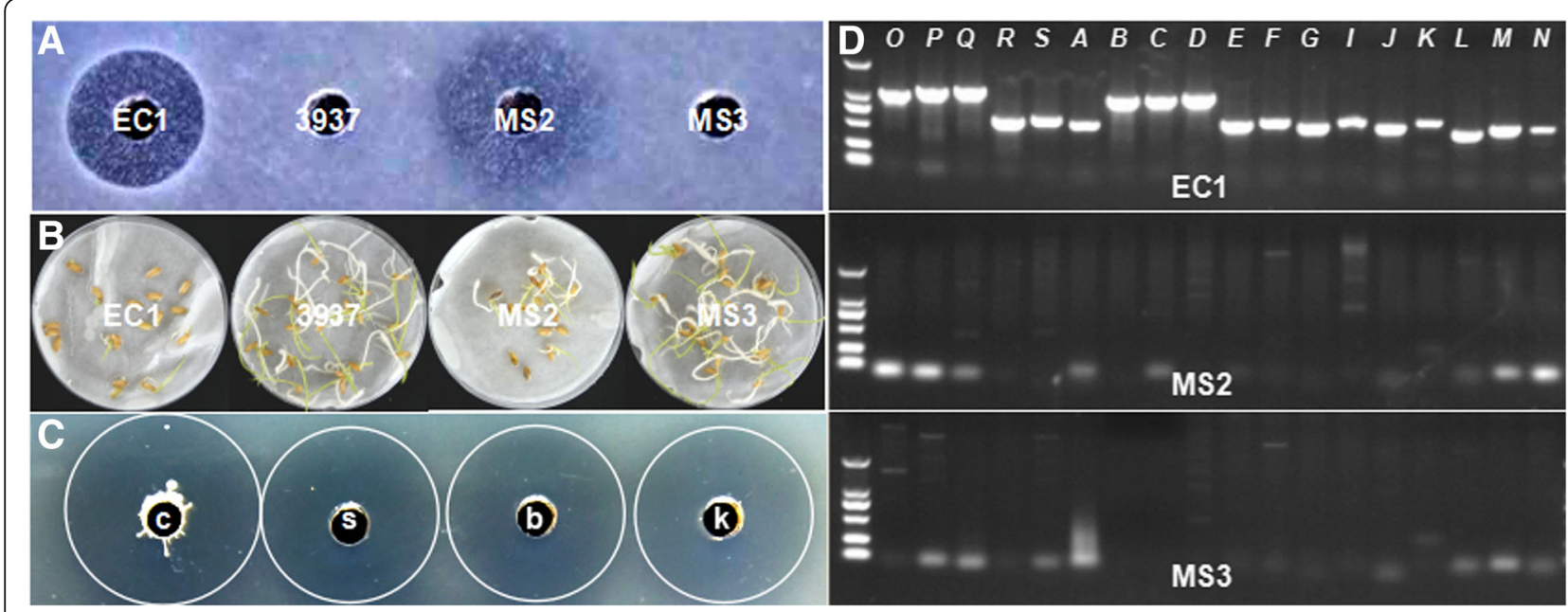

Fig. 5 Phytotoxins produced by Dickeya strains. a, Bioassay of toxin production. b. Inhibitory activity of toxins from Dickeya strains against rice seed germination. Bacteria were grown in $\mathrm{LB}$ medium till $\mathrm{OD}_{600}=1.5$, and 20 seeds of rice variety $\mathrm{CO} 39$ were added to $5 \mathrm{ml}$ of every bacterial culture and incubated at room temperature for $5 \mathrm{~h}$, which were then cleaned and transferred onto a Petri dish with filter paper on it, and then incubated at $28{ }^{\circ} \mathrm{C}$ under $16 \mathrm{~h} \mathrm{light}$ and $8 \mathrm{~h}$ dark conditions. Rice seeds incubated with same amount of D. dadantii 3937 were used as a control. c, The toxin produced by MS2 is an extracellular nonprotein metabolite. Strain MS2 was grown in LS5 medium till OD $600=1.5$ (c), and supernatant of the culture (s) was collected, which was treated by boiling at $100{ }^{\circ} \mathrm{C}$ for $10 \mathrm{~min}$ (b) or digestion with protease $\mathrm{K}$ at $37^{\circ} \mathrm{C}$ for 30 min ( $\mathrm{k}$ ). Finally, the inhibition activity against the growth of $E$. coli DH5a was measured. $\mathbf{d}$, PCR detection of zeamines biosynthesis genes from zmsO to zms $N$. Based on the coding sequences of zms gene cluster in strain EC1 [43], 18 pairs of primers corresponding to $z m s O$ to $z m s N$ were designed to detect the zeamine biosynthsis gene cluster in D. zeae strains, which are presented in Additional file 4. The DNA marker is DL2000

In combination with the sequencing results of MS2 genome (unpublished results), we confirmed that the phytotoxin(s) produced by $D$. zeae MS2 is probably novel, encoded by biosynthesis genes different from the zms gene cluster [43].

To investigate whether this phytotoxin(s) is toxic to nematodes, like zeamines produced by $S$. plymuthica A153 [62], we tested the nematode-killing dynamics of the two strains producing toxins. The results showed that both strains EC1 and MS2 had nematocidal activities, with similar slow-killing activity on NGM medium (Fig. 6a), whereas, strain EC1 had faster speed in killing C. elegans on PGS medium than strain MS2 (Fig. 6b).
We inferred that the toxins produced by strains MS2 and EC1 may have similar killing effect on nematodes in the NGM medium. In the fast-killing assay, the worms treated with strain EC1 quickly became immobilized, and were completely dead in $12 \mathrm{~h}$ after treatment, while worms on strain MS2 lawn seemed more energetic and remained alive for a longer time compared with those on strain EC1 lawn, with only about $51 \%$ of worms died at $12 \mathrm{~h}$, and $100 \%$ death occurred at $72 \mathrm{~h}$ after treatment (Fig. 6b), suggesting that the toxin(s) produced by strain MS2 was less toxic to C. elegans than zeamines produced by strain EC1 in the PGS medium.
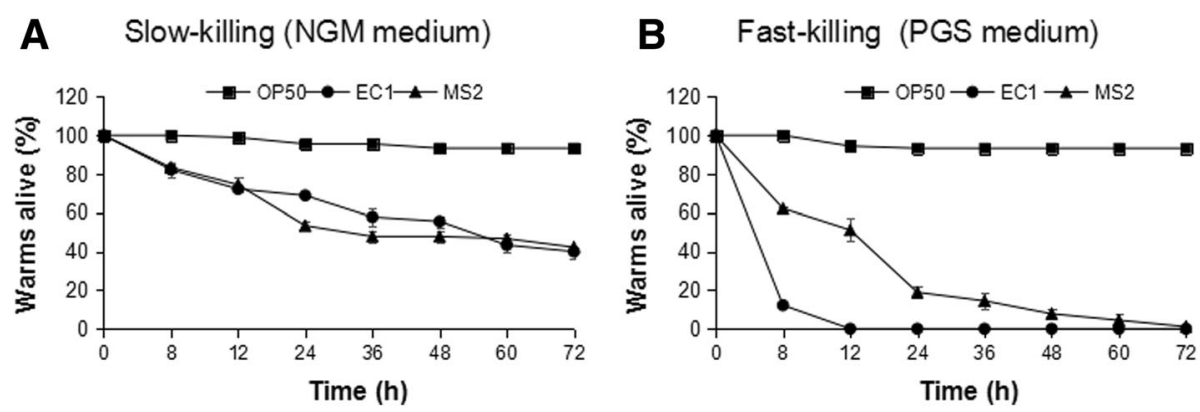

Fig. 6 Worm-killing assay of D. zeae strains towards C. elegans. a Slow-killing; b Fast-killing. Strains EC1 and MS2 were grown in LB medium at $28^{\circ} \mathrm{C}$ and the C. elegans food-source E. coli OP50 (negative control) at $37^{\circ} \mathrm{C}$ overnight, and $50 \mu \mathrm{L}$ of the liquid culture was spotted onto the center of NGM (slow-killing) (a) or PGS (fast-killing) (b) agar plates and allowed to dry thoroughly. In the slow-killing assay, $50 \mu \mathrm{M}$ of floxuridine (FudR, Sigma) was added into NG agar to inhibit hatching of nematode eggs [58]. The plates containing bacteria were incubated at $28^{\circ} \mathrm{C}$ and $37^{\circ} \mathrm{C}$ respectively overnight and cooled for at least $2 \mathrm{~h}$ at room temperature before adding $30 \mathrm{~L} 4$ stage or adult hermaphrodite worms. The plates were kept at $20^{\circ} \mathrm{C}$, and live worms were scored 
Furthermore, the inhibition activity of Dickeya strains against some important pathogenic microorganisms was measured. Results showed that $D$. dadantii 3937 had little antimicrobial activity against all the tested microorganisms (Table 2). For the tested pathogenic bacteria, D. zeae EC1 showed the strongest antimicrobial effect with obvious antimicrobial halo zone on the pathogens except Ralstonia solanacearum EP1, while strains isolated from banana had little antibacterial activity except that strain MS2 inhibited the growth of E. coli DH5 $\alpha$ (Table 2). The antifungal activity of EC1 was strongest, followed by strains MS2 and MS3, and the antagonistic activity of the $D$. zeae strains isolated from banana indicated that it is not the new toxin produced by MS2 that has the antifungal activity, since strain MS3 showed a similar antifungal activity as strain MS2 (Table 2).

\section{D. zeae JZL strains have stronger cell motility than other strains}

Bacterial motility is of important pathological significance during the early stage of infection. In this study, the mobile capability of $D$. zeae strains was measured including swimming and swarming motility. Results showed that all the strains were capable of swimming and swarming, but in general, the strains isolated from clivia swarmed and swam faster than the other strains, except that strain JZL7 swarmed similar to strain MS2 (Fig. 7). Given that JZL strains were weaker than the other three strains in production of various virulence factors but showed comparable virulence against Clivia miniata (Fig. 4, Table 1, Additional file 3), we reasoned that the cell motility of JZL strains might contribute substantially in their pathogenicity against the clivia plants, which awaits further investigations.

\section{Discussion}

D. zeae is a kind of pectinolytic bacteria causing soft rot disease on plants all over the world. It usually causes great agricultural economic losses in tropical, subtropical and temperate regions, especially in Southeast Asian countries such as Japan, Philippines, Bangladesh, China, India, Indonesia, South Korea, North Korea and Malaysia on maize, rice and banana (Additional file 1) [3, 14, 15, 19, 24, 26]. So far, the host range of $D$. zeae includes 25 dicotyledonous plants, and 18 monocotyledonous plants including the natural host clivia expanded in this study (Additional file 1).

By comparing the geographical distribution of D. zeae, we found that this species is centralized on monocot hosts in Asia (Additional file 1), similar to the situation that $D$. solani bacteria were mostly found in European countries and Israel on potato [10, 63]. The centralized distribution of $D$. zeae is probably due to the growth environment or host specificity related to bacterial evolution and adaptation during plant-pathogen interactions. According to our previous study, we found that the genome sequences of D. zeae rice strains EC1 and ZJU1202, both isolated from Guangdong Province, share 99.962\% identity, while strain EC1 is only $95.863 \%$ identical to the rice strain DZ2Q isolated from Italy, and interestingly, all these three rice strains harbor an unique $z m s$ gene cluster encoding zeamines, which was absent in other sequenced D. zeae strains isolated from other sources $[11,43]$, suggesting that this $z m s$ gene cluster is probably related to their rice host specificity. In this study, we also found that strains MS2 and MS3, both isolated from banana, could not produce zeamines (Fig. 5), but strain MS2 produces another type of antimicrobial compounds with moderate inhibition activities on rice seed germination and nematicidal activity (Figs. 5 and 6), while strain MS3 produces none, in addition, strain MS2 showed higher pectinolytic activity, faster motility, and stronger virulence than strain MS3, indicating the complicated and dynamic process of $D$. zeae evolution.

Table $\mathbf{2}$ Inhibition activity of Dickeya strains against some pathogenic microorganisms

\begin{tabular}{|c|c|c|c|c|c|c|}
\hline \multirow[t]{2}{*}{ Microorganism } & \multirow[t]{2}{*}{ Description } & \multirow{2}{*}{$\begin{array}{l}\text { Source or } \\
\text { reference }\end{array}$} & \multicolumn{4}{|c|}{ Inhibition activity (mm) } \\
\hline & & & $\mathrm{EC1}$ & MS2 & MS3 & 3937 \\
\hline Escherichia coli DH5a & Indicator for toxin antagonism & Lab storage & $5.23 \pm 0.23$ & $7.51 \pm 0.34$ & 0 & 0 \\
\hline Ralstonia solanacearum EP1 & Pathogen of eggplant bacterial wilt & {$[68]$} & 0 & 0 & 0 & 0 \\
\hline Xanthomonas campestris pv. campestris Xc1 & Pathogen of crucifers black rot & [69] & $9.68 \pm 0.36$ & 0 & 0 & 0 \\
\hline Pseudomonas aeruginosa PAO1 & Pathogen of cystic fibrosis & {$[70]$} & $4.04 \pm 0.43$ & 0 & 0 & 0 \\
\hline Fusarium oxysporum f.sp. cubense FOC4 & Pathogen of banana wilt & {$[71]$} & $6.17 \pm 0.33$ & $3.95 \pm 0.39$ & $3.32 \pm 0.22$ & 0 \\
\hline Rhizoctonia solani AG-1 IA & Pathogen of rice sheath blight & {$[72]$} & $4.07 \pm 0.23$ & $1.31 \pm 0.09$ & $0.70 \pm 0.15$ & 0 \\
\hline Magnaporthe oryzae B157 & Pathogen of rice blast & [73] & $4.70 \pm 0.28$ & $1.98 \pm 0.34$ & $1.50 \pm 0.31$ & 0 \\
\hline Peronophythora litchi & Pathogen of litchi downy blight & {$[74]$} & $11.69 \pm 0.34$ & $8.71 \pm 0.15$ & $3.48 \pm 0.21$ & $3.72 \pm 0.22$ \\
\hline Colletotrichum capsici & Pathogen of capsicum anthracnose & Lab storage & $5.45 \pm 0.14$ & $5.26 \pm 0.13$ & $4.79 \pm 0.10$ & 0 \\
\hline C. gloeosporioides & Pathogen of mango anthracnose & Lab storage & $4.91 \pm 0.10$ & $4.06 \pm 0.20$ & $3.59 \pm 0.42$ & 0 \\
\hline Sporisorium scitamineum & Pathogen of sugarcane smut & {$[75]$} & $2.60 \pm 0.06$ & $2.27 \pm 0.54$ & $1.51 \pm 0.22$ & 0 \\
\hline
\end{tabular}



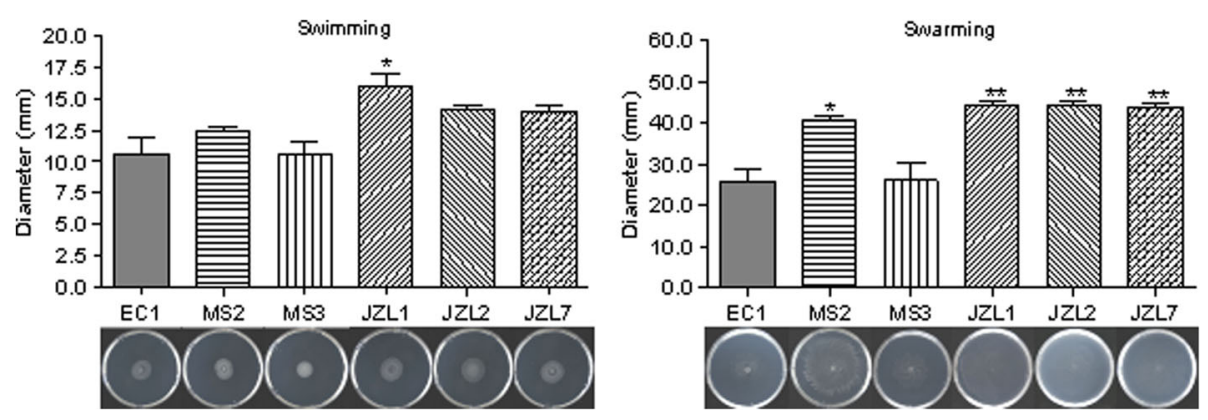

Fig. 7 Cell motility of D. zeae strains. One microlitre of bacterial culture $\left(\mathrm{OD}_{600}=1.5 \mathrm{in} \mathrm{LB}\right.$ medium) was spotted onto the centre of a plate containing about $20 \mathrm{~mL}$ of semisolid swimming or swarming medium, which was then incubated at $28^{\circ} \mathrm{C}$ for $20 \mathrm{~h}$ before measurement of the diameters of bacterial motility zone

We also isolated D. zeae strains from ornamental monocot plant Clivia miniata and validated them as the causal agents of clivia soft rot disease. Although MS2, MS3 and JZL strains are in a same big branch of $D$. zeae, they fall in different clades of the $16 S \mathrm{rDNA}$ tree and the joint phylogenetic tree (Figs. 1 and 2). Given that $16 S$ $r D N A$ gene sequence is insufficient to assign the taxonomy of a bacterium owing to its polyphyletic nature not only in a same family, but also in a same genus [64], we consider that the joint phylogenetic tree based on MLSA analysis is more reliable. Phenotypic characteristics of virulence factors indicated that $D$. zeae clivia strains JZLs produce remarkably less extracellular degrading enzymes than other strains, especially proteases (Fig. 4), probably responsible for the significantly narrower host range and the extremely less virulence on the tested hosts except clivia (Table 1 ). In contrast, D. zeae strains JZLs caused a comparable disease severity on clivia with the rice and banana strains (Table 1), which may suggest that these JZL strains have stronger affinity on their natural host plant than non-natural host.

The differences in production of virulence factors and bacterial aggressiveness among strains suggest that $D$. zeae strains causing soft rot disease are highly diverse whether from different sources or from the same host. Indeed, it has already been reported that D. solani strains from different climatic conditions, despite their genotypic homogeneity, behave very differently under particular environmental conditions, especially the incubation temperature [65]. The diversity in virulence factors and infection ability is not solely specific to certain species, rather, it is strain characteristic $[66,67]$.

The narrower host range and the lower pathogenicity of $D$. zeae JZL strains may be attributed to the loss of some important pathogenic islands during the evolution along with host clivia. Actually, in a long period of evolution and interaction with host plants, gene deletions and additional acquisition frequently occur, for instance, the $z m s$ gene cluster in $D$. zeae rice strains associated with the rice host specificity $[11,43,60]$, and probably the genes encoding the antimicrobial compound(s) in strain MS2. Aggressiveness of D. zeae strains showed that EC1, MS2 and MS3 strains grew faster in potato and clivia than in cabbage and banana (Fig. 3), probably because the former two plants could provide more carbon sources for the bacterial growth. And the cell numbers of all the strains in banana tissues seemed comparable (Fig. 3c), while the disease degree caused by JZL strains was obviously lower than that caused by the other strains (Table 1, Additional file 3). We considered that the decreased virulence of JZL strains on monocotyledonous hosts is unrelated to the bacterial growth speed, which was also verified in Fig. 4a, but due to the reduced production of CWDEs (Fig. 4b).

Moreover, the antimicrobial compound(s) produced by strain MS2 is one of the major virulence factors inhibiting rice seed germination and killing nematodes. Genes encoding this new toxin(s) are being identified and the effects on rice seeds are being investigated. Whole genome comparison of these Dickeya zeae strains will be helpful for identification of the host-specific genes among $D$. zeae strains and revealing the interactions between pathogens and hosts.

\section{Conclusions}

In this study, we identified the causal agents respectively from soft rot banana and clivia plants as Dickeya zeae. To our knowledge, this is the first time reporting clivia as the natural host of D. zeae. After comparing the virulence factors produced by different $D$. zeae strains isolated from rice, banana and clivia, we concluded that at least two types of $D$. zeae strains cause soft rot disease of banana, one of which produces a novel phytotoxin different from zeamines, while the other produces none, and the clivia isolates only infect monocots because of their weak aggressiveness on dicots. The virulence differentials of strains may provide targets for controlling bacterial soft rot diseases caused by Dickeya. 


\section{Methods}

D. zeae strains collection, isolation and identification Bacterial strains used in this study were listed in Additional file 4. D. zeae strain EC1 was isolated from diseased rice stem foot [11]. Strains MS2 and MS3 were isolated from the basal pseudostems of banana plants with soft rot disease respectively collected from Nansha and Panyu Districts in Guangzhou, Guangdong Province in 2012. D. zeae JZL strains were isolated from Clivia miniata (belonging to Amaryllidaceae) plants with soft rot symptoms at Fangcun flower market in Guangzhou city, Guangdong Province, China in 2017. D. dadantii 3937 isolated from African violets was also used for testing the virulence factors as a control.

MS2, MS3 and JZL strains that fulfilled Koch's postulates were identified by sequencing of $16 S$ rRNA gene using 27F/1492R primers [46], and $a t p D, \operatorname{gyr} B$, infB and rрo $B$ genes using primers and PCR conditions listed by Brady et al. [47]. DNA fragments were amplified using EasyTaq DNA polymerase (Transgen) and cloned into pUC19-T vector for sequencing. The sizes of the resultant amplicons were as follows: $16 S$ rRNA, 1507 bp; atpD, 884 bp; gyrB, 974 bp; infB, 1124 bp; rpoB, 1090 bp.

\section{Multilocus sequences analysis (MLSA) and phylogenetic analysis}

Sequence similarities of all genes were determined by using BLASTn program, and all the sequences of related strains were obtained from GenBank database. Consensus sequences were aligned with ClustalW and trimmed in the following sizes: $16 S \operatorname{rRNA}, 654 \mathrm{bp}$; atpD, $642 \mathrm{bp}$; gyrB, 745 bp; $\operatorname{infB}, 1042 \mathrm{bp} ; r p o B, 1000 \mathrm{bp}$. All the sequences of a same strain except $16 S$ rRNA were assembled for constructing a joint phylogenetic tree. Neighbor-joining trees were constructed by bootstrap analysis with 1000 replicates using MEGA5 package [48]. The GenBank accession numbers of $16 S$ rRNA, atpD, $g y r B$, infB and rpo $B$ gene sequences of strain MS2 are MF973080, MG018807, MG018810, MG018813 and MG018816, respectively, those of strain MS3 are MF973081, MG018808, MG018811, MG018814 and MG018817, respectively, and those of strain JZL are MF973082, MG018809, MG018812, MG018815 and MG018818, respectively.

\section{Pathogenicity assay against monocotyledonous and dicotyledonous plants}

The tested strains were grown in LB medium till $\mathrm{OD}_{600}=$ 1.5 , and different plant organs of monocotyledons and dicotyledons listed in Table 1 were selected using different inoculation methods. For rice (Oryza sativa), banana (Musa sapientum ABB), Gladiolus gandavensis and Alocasia macrorrhiza, every $200 \mu \mathrm{L}$ of bacterial cultures was injected into the basal stems of the seedlings, and into the bases of clivia leaves. For radish (Raphanus sativus), carrot (Daucus carota), potato (Solanum tuberosm), Zingiber officinale, and Colocasia esculenta, tubers were washed with tap water and dried with a paper towel, subsequently, surface-sterilized with $70 \%$ ethanol and then sliced evenly about $5 \mathrm{~mm}$ in thickness. Each slice was placed in a tray with moistened filter paper. Other plant materials to be inoculated were surface-sterilized. Bacterial cells of $2 \mu \mathrm{L}$ were applied to the inoculated parts after piercing them with pipette tips except eggplant (Solanum melongena) and tomoto (Lycopersicon esculentum) inoculated with $100 \mu \mathrm{L}$ of bacterial cultures. All trays were kept at $28{ }^{\circ} \mathrm{C}$ till symptoms appeared. Same volume of LB medium was inoculated as a negative control. Each assay was repeated three times with triplicates. The area of lesions were measured using Image J software.

\section{Tests on aggressiveness of $D$. zeae strains}

The tested strains were grown in LB medium till $\mathrm{OD}_{600}=$ 2.0. Healthy potato tubers, cabbage petiole, banana pseudostems and clivia leaves were selected, washed with tap water, surface-sterilized with $70 \%$ ethanol, and placed onto the moistened filter paper in plates in biosafety cabinet under UV sterilization for $15 \mathrm{~min}$. The plant tissues were pierced and inoculated with $2 \mu \mathrm{L}$ of bacterial cultures. Plates were incubated at $28{ }^{\circ} \mathrm{C}$. Same volume of LB medium was inoculated as a negative control. Tissues were taken out after $12 \mathrm{~h}$ and $24 \mathrm{~h}$ of incubation, respectively, where the diseased and surrounding healthy tissues in equal weight were cut and ground, then added with $10 \mathrm{~mL}$ of sterilized $0.85 \% \mathrm{NaCl}$ solution, stirred evenly, and $1 \mathrm{~mL}$ of which was taken and diluted into $10^{3}, 10^{4}$, and $10^{5}$ folds, and then $100 \mu \mathrm{L}$ in each dilution gradient was spread evenly onto LB agar plates in triplicates. Plates were kept at $28{ }^{\circ} \mathrm{C}$ for $24 \mathrm{~h}$, and colonies between 30 to $300 \mathrm{CFU}$ (Colony-Forming Unit) were counted. Each assay was repeated three times with duplicates.

\section{Measurement of bacterial growth curves}

Bacterial strains to be tested were grown in LB medium overnight at $28{ }^{\circ} \mathrm{C}$. All the bacterial cultures were adjusted to $\mathrm{OD}_{600}=2.0$ and diluted into fresh LB medium in 1:100 ratio. Dilutions were mixed thoroughly and aliquots of $500 \mu \mathrm{L}$ were transferred into $2.0 \mathrm{~mL}$ tubes. Bacteria were grown with shaking at $200 \mathrm{r} / \mathrm{min}$ under $28{ }^{\circ} \mathrm{C}$ and cell density was measured at $0,4,8,12,16,20,24$, 28 and $40 \mathrm{~h}$ respectively. The experiment was repeated three times in triplicate.

\section{Measurement of cell wall degrading enzymatic (CWDE) activities}

The activities of cell wall degrading enzymes were measured using the medium recipe described previously [49-51]. Briefly, assay medium was prepared, and $30 \mathrm{~mL}$ 
of each medium was poured into a $12 \times 12 \mathrm{~cm}$ square plate. Subsequently, wells (4 $\mathrm{mm}$ in diameter) were punched after solidification. Samples of $40 \mu \mathrm{L}$ bacterial cells were added into the wells after they had grown to $\mathrm{OD}_{600}=1.8$. All plates were incubated at $28{ }^{\circ} \mathrm{C}$. Pectate lyase (Pel) and polygalacturonase (Peh) assay plates were covered with $4 \mathrm{~N} \mathrm{HCl}$ after $11 \mathrm{~h}$ and $14 \mathrm{~h}$ respectively. Cellulase (Cel) assay plate was stained with $0.1 \%(w / v)$ Congo Red for $15 \mathrm{~min}$ after $14 \mathrm{~h}$, and treated with $1 \mathrm{M}$ $\mathrm{NaCl}$ twice. Protease (Prt) activity was indicated by the transparent halos surrounding the wells after $24 \mathrm{~h}$ incubation. The experiment was repeated three times with duplicates.

\section{Assay of extracellular polysaccharide (EPS) production}

Extracellular polysaccharides (EPS) are one of the important virulence factors for bacterial phytopathogens and the main toxic factors leading to water-logging and wilting on plants after infection [52-54]. For measuring the production of EPS, single colonies of the tested strains were picked and transferred into $10 \mathrm{~mL} \mathrm{LB}$ medium for culture overnight at $28{ }^{\circ} \mathrm{C}$ until $\mathrm{OD}_{600}=1.8$, afterwards, $3 \mathrm{~mL}$ of which was applied into $300 \mathrm{~mL} \mathrm{LB}$ medium, and grown with shaking at $200 \mathrm{r} / \mathrm{m}$ for $12 \mathrm{~h}$. Cultures were centrifuged at $8000 \mathrm{rpm}$ for $40 \mathrm{~m}$, and then at $4000 \mathrm{rpm}$ for $20 \mathrm{~m}$ to obtain $250 \mathrm{~mL}$ supernatants. Double volumes of absolute ethanol were added to the supernatants, mixed thoroughly, stored at $4{ }^{\circ} \mathrm{C}$ overnight for precipitation, and subjected to centrifugation at $8000 \mathrm{rpm}$ for $40 \mathrm{~m}$. Finally, supernatants were discarded and pellets were weighed after drying at $55{ }^{\circ} \mathrm{C}$ overnight. The experiment was repeated three times in triplicate.

\section{Toxin bioassay}

The tested strains were streaked on LB plates and single colonies were transferred into LS5 medium [55] to grow at $28{ }^{\circ} \mathrm{C}$ overnight. Cell density was adjusted to $\mathrm{OD}_{600}=$ 1.5 prior to bioassay. The bioassay plate was prepared as previous described [44]. Wells of $4 \mathrm{~mm}$ in diameter were punched in the plate and $20 \mu \mathrm{L}$ of the bacterial cultures were added into the wells. The plate was incubated overnight at $37{ }^{\circ} \mathrm{C}$.

To preliminarily determine the chemical property of the toxin, supernatant of strain MS2 overnight culture was collected, and treated by boiling at $100{ }^{\circ} \mathrm{C}$ for $10 \mathrm{~min}$ and by digestion with protease $\mathrm{K}$ at $37{ }^{\circ} \mathrm{C}$ for $30 \mathrm{~min}$, respectively. Finally, the inhibition activity against the growth of E. coli $\mathrm{DH} 5 \alpha$ was measured. The experiment was repeated three times in triplicate.

\section{Inhibition of phytotoxins against rice seed germination} Bacteria were grown in LB medium till $\mathrm{OD}_{600}=1.5$, and 20 seeds of rice variety $\mathrm{CO} 39$ were added to $5 \mathrm{ml}$ of every bacterial culture and kept at room temperature for
$5 \mathrm{~h}$, then taken out to clean in sterilized water and transferred onto the moistened filter paper in a Petri dish, which was then kept at $28{ }^{\circ} \mathrm{C}$ under $16 \mathrm{~h}$ light and $8 \mathrm{~h}$ dark conditions. Rice seeds incubated with same amount of $D$. dadantii 3937 were used as a control. The experiment was repeated three times in triplicate.

\section{Detection of zeamine biosynthesis gene cluster}

Based on the coding sequences of $z m s$ gene cluster in strain EC1 [43], we designed 18 pairs of primers (Additional file 5) corresponding to $z m s O$ to $z m s N$ to detect the zeamine biosynthsis gene cluster in $D$. zeae strains, which are presented in Additional file 4. DNA fragments were amplified using EasyTaq DNA polymerase (Transgen) using conditions as following: $95^{\circ}$ C, 2 min; 30 cycles of $94{ }^{\circ} \mathrm{C}, 30 \mathrm{~s}, 55^{\circ} \mathrm{C}, 30 \mathrm{~s}$ and $72{ }^{\circ} \mathrm{C}, 1 \mathrm{~min} ; 72^{\circ} \mathrm{C}, 5 \mathrm{~min}$.

\section{Antimicrobial activity assay}

Pathogenic microorganisms used in this study were listed in Table 2, in which, bacterial pathogens were grown in LB medium overnight and fungi were grown on PDA medium at $28{ }^{\circ} \mathrm{C}$ until colonies covered the Petri dishes. For antibacterial activity, the same method of toxin bioassay against $E$. coli described in previous section was used against other bacterial pathogens, and the diameters of the antibacterial halos were measured. For antifungal activity, fungal dishes in diameter of $4 \mathrm{~mm}$ were punched and placed onto the center of PDA plate, and $2 \mu \mathrm{L}$ of EC1, MS2, MS3 and 3937 strain overnight cultures were respectively spotted onto each of the four sides of the fungal dishes $(3 \mathrm{~cm}$ away from the edge of the fungal dishes). Plates were incubated at $28{ }^{\circ} \mathrm{C}$ until fungal colonies on blank plates covered the petri dishes, and the distance between bacterial colonies and the hyphal edge of the tested fungi was measured. The experiment was repeated three times.

\section{Nematode killing activity}

Wild type Caenorhabditis elegans were maintained according to the methods as previously described [56], and the medium recipe for worm-killing assays was referred to in literature reported by Tan et al. [57]. D. zeae strains EC1 and MS2 were routinely grown in LB medium at $28^{\circ} \mathrm{C}$ and the C. elegans food-source E. coli OP50 at $37^{\circ}$ $\mathrm{C}$ overnight, and $50 \mu \mathrm{L}$ of the liquid culture was spotted onto the center of PGS (fast-killing) or NGM (slow-killing) agar plates and allowed to dry thoroughly. In the slow-killing assay, $50 \mu \mathrm{M}$ of floxuridine (FudR, Sigma) was added into NG agar to inhibit hatching of nematode eggs [58]. E. coil OP50 culture was used as a negative control. The plates containing bacteria were incubated at $28{ }^{\circ} \mathrm{C}$ and $37{ }^{\circ} \mathrm{C}$ respectively overnight and cooled for at least $2 \mathrm{~h}$ at room temperature before adding $30 \mathrm{~L} 4$ 
stage or adult hermaphrodite worms. The plates were kept at $20{ }^{\circ} \mathrm{C}$, and live worms were scored. Each trial was repeated three times in triplicate.

\section{Measurement of cell motility}

To determine the cell motility, media for swimming (per litre contains $10 \mathrm{~g}$ bactotryptone, $5 \mathrm{~g} \mathrm{NaCl}$ and $3 \mathrm{~g}$ agar) and swarming (per litre contains $5 \mathrm{~g}$ peptone, $3 \mathrm{~g}$ yeast extract and $4 \mathrm{~g}$ agar) assay were prepared. One microlitre of overnight bacterial culture $\left(\mathrm{OD}_{600}=1.5\right)$ was spotted onto the centre of a plate containing about $20 \mathrm{~mL}$ of .each medium. The plates were incubated at $28{ }^{\circ} \mathrm{C}$ for $20 \mathrm{~h}$ before measurement of the diameters of bacterial motility zone. Each experiment was repeated at least three times in triplicate [44].

\section{Statistic analysis}

All the experiments were repeated in three times with duplicates or triplicates. For statistic analysis, GraphPad Prism 5.0 software was used to performed Student's $t$ test, and the data of $D$. zeae strains were normalized to those of strain EC1. " indicates $P<0.05$, ** indicates $P<$ 0.001 , and $\%$ indicates $P<0.0001$.

\section{Additional files}

Additional file 1: The hosts and origins of D. zeae strains. (DOC $92 \mathrm{~kb}$ )

Additional file 2: Natural hosts and distribution of $D$. zeae strains in southeast Asia. The map was drawn using Photoshop CS6 software and host plant icons were added on the corresponding locations of the map. (TIF $2891 \mathrm{~kb}$ )

Additional file 3: The diseased symptoms of the tested strains on dicotyledonous and monocotyledonous hosts corresponding to Table 1. (PDF $6199 \mathrm{~kb}$ )

Additional file 4: Bacterial strains used in this study. (DOC $36 \mathrm{~kb}$ )

Additional file 5: Primers used in this study for detection of zeamines biosynthesis genes. (DOC 54 kb)

\section{Abbreviations}

AHL: Acyl homoserine lactone; Cel: Cellulases; CWDE: Cell wall degrading enzyme; EPS: Extracellular polysaccharides; MLSA: Multilocus sequences analysis; Peh: Polygalacturonases; Pel: Pectate lyases; Prt: Proteases; QS: Quorum sensing

\section{Acknowledgments}

We are very grateful to Dr. Xiaoming Pu in Plant Protection Research Institute, Guangdong Academy of Agricultural Sciences for his great help in the field investigation of banana soft rot disease.

\section{Funding}

This work was supported by a grant from the National Key Project for Basic Research of China (973 Program) (No. 2015CB150600) and by grants from the Science and Technology Planning Project of Guangdong Province, China (No. 2017A010105009), and Guangdong Province "Innovation and University Development" Project (No. 2016KZDXM026). The funding bodies had no role in the design of the study and collection, analysis, and interpretation of data and in writing this manuscript.

\section{Availability of data and materials}

The data sets supporting the results of this article are included within the article and its Additional files. In addition, specimens were collected and taken according to the guidelines of the Chinese "Biosafty Management Regulations for Pathogenic Microbiological Laboratory".

\section{Authors' contributions}

$J Z$ conceived the study, drafted and coordinated the manuscript, $M H, R C$ $W L, L F, L S, Y X, J L$ and $X F$ performed the experiments, $M H$ and $J Z$ analyzed the data, $L Z$ and $J Z$ revised the manuscript. All authors read and approved the final manuscript

Ethics approval and consent to participate

Not applicable.

\section{Consent for publication}

Not applicable.

\section{Competing interests}

The authors declare that they have no competing interests.

\section{Publisher's Note}

Springer Nature remains neutral with regard to jurisdictional claims in published maps and institutional affiliations.

\section{Author details}

${ }^{1}$ Integrative Microbiology Research Centre, South China Agricultural University, Guangzhou 510642, China. ${ }^{2}$ Guangdong Province Key Laboratory of Microbial Signals and Disease Control, Department of Plant Pathology, South China Agricultural University, Guangzhou 510642, China.

Received: 30 July 2018 Accepted: 1 October 2018

Published online: 18 October 2018

References

1. Liu G. List of Plant Quarantine Pests in the People's Republic of China. Pestic Mark Inf. 2007:13:40-1 (in Chinese).

2. Mansfield J, Genin S, Magori S, Citovsky V, Sriariyanum M, Ronald P, Dow M, Verdier V, Beer SV, Machado MA, Toth I, Salmond G, Foster GD. Top 10 plant pathogenic bacteria in molecular plant pathology. Mol Plant Pathol. 2012; 13:614-29.

3. Samson R, Legendre JB, Christen R, Fischer-Le Saux M, Achouak W, Gardan L. Transfer of Pectobacterium chrysanthemi (Burkholder et al. 1953) Brenner et al. 1973 and Brenneria paradisiaca to the genus Dickeya gen. nov. as Dickeya chrysanthemi comb. nov. and Dickeya paradisiaca comb. nov. and delineation of four novel species, Dickeya dadantii sp. nov., Dickeya dianthicola sp. nov., Dickeya dieffenbachiae sp. nov. and Dickeya zeae sp. nov. Int J Syst Evol Microbiol. 2005;55(4):1415-27. https://doi.org/10. 1099/ijs.0.02791-0

4. Brady C, Cleenwerck I, Denman S, Venter SN, Rodriquez-Palenzuela P, Coutinho TA, Devos P. Proposal to reclassify Brenneria quercina (Hildebrand and Schroth 1967) Hauben et al. 1999 into a new genus, Lonsdalea gen. nov., as Lonsdalea quercina comb. nov., descriptions of Lonsdalea quercina subsp. quercina comb. nov., Lonsdalea quercina subsp. iberica subsp. nov. and Lonsdalea quercina subsp. britannica subsp. nov., emendation of the description of the genus Brenneria, reclassification of Dickeya dieffenbachiae as Dickeya dadantii subsp. dieffenbachiae comb. nov., and emendation of the description of Dickeya dadantii. Int J Syst Evol Microbiol. 2012;62(7): 1592-602.

5. Parkinson N, Devos P, Pirhonen M, Elphinstone J. Dickeya aquatica sp nov., isolated from waterways. Int J Syst Evol Microbiol. 2014;64(7):2264-6.

6. Tian Y, Zhao Y, Yuan X, Yi J, Fan J, Xu Z, Hu B, De Boer SH, Li X. Dickeya fangzhongdai sp. nov., a plant-pathogenic bacterium isolated from pear trees (Pyrus pyrifolia). Int J Syst Evol Microbiol. 2016;66(8):2831-5.

7. Hussain MB, Zhang HB, Xu JL, Liu Q, Jiang Z, Zhang LH. The acylhomoserine lactone-type quorum-sensing system modulates cell motility and virulence of Erwinia chrysanthemi pv. zeae. J Bacteriol. 2008;190(3):104553. https://doi.org/10.1128/JB.01472-07.

8. Sławiak M, van Beckhoven JRCM, Speksnijder AGCL, Czajkowski R, Grabe G, van der Wolf JM. Biochemical and genetical analysis reveal a new clade of biovar 3 Dickeya spp. strains isolated from potato in Europe. Eur J Plant Pathol. 2009;125:245-61.

9. Lin BR, Shen HF, Pu XM, Tian XS, Zhao WJ, Zhu SF, Dong MM. First report of a soft rot of banana in Mainland China caused by a Dickeya sp. (Pectobacterium chrysanthemi). Plant Dis. 2010;94:640. 
10. Toth IK, van der Wolf JM, Saddler G, Lojkowska E, Hélias V, Pirhonen M, Tsror L, Elphinstone JG. Dickeya species: an emerging problem for potato production in Europe. Plant Pathol. 2011;60:385-99.

11. Zhou JN, Zhang HB, Wu J, Liu QG, Xi PG, Lee J, Liao JL, Jiang ZD, Zhang LH. A novel multi-domain polyketide synthase is essential for zeamine antibiotics production and the virulence of Dickeya zeae. Mol Plant-Microbe Interact. 2011;24(10):1156-64. https://doi.org/10.1094/MPMI-04-11-0087.

12. Zhang JX, Shen HF, Pu XM, Lin BR. Identification of Dickeya zeae as a casual agent of bacterial soft rot in banana in China. Plant Dis. 2014;98(4): $436-42$.

13. Sinha SK, Prasad M. Bacterial stalk rot of maize, its symptoms and host-range. Zentralbl Bakteriol Parasitenkd Infektionskr Hyg. 1977;132: $81-8$

14. Goto M. Bacterial Foot Rot of Rice Caused by a Strain of ErwiniaChrysanthemi. Phytopathology. 1979;69(3):213-6. https://doi.org/10.1094/ Phyto-69-213

15. Liu QG, Wang ZZ. Infection characteristics of Erwinia chrysanthemi pv. zeae on rice. J S China Agric Univ. 2004;25:55-7 (in Chinese).

16. Jafra S, Przysowa J, Gwizdek-Wiśniewska A, van der Wolf JM. Potential of bulb-associated bacteria for biocontrol of hyacinth soft rot caused by Dickeya zeae. J Appl Microbiol. 2008;106:268-77.

17. Stead DE, Parkinson N, Bew J, Hennessy J, Wilson JK, Elphinstone JE. The first record of Dickeya zeae in the UK. Plant Pathol. 2010;59:401.

18. Myung IS, Jeong IH, Moon SY, Kim WG, Lee SW, Lee YH, Lee YK, Shim HS, Ra DS. First report of bacterial stalk rot of sweet corn caused by Dickeya zeae in Korea. New Dis Rep. 2010;22:236-50.

19. Li B, Shi Y, Ibrahim M, Liu H, Shan C, Wang Y, Kube M, Xie GL, Sun G. Genome sequence of the rice pathogen Dickeya zeae strain ZJU1202. J Bacteriol. 2012;194(16):4452-3.

20. Bertani I, Passos da Silva D, Abbruscato P, Piffanelli P, Venturi V. Draft genome sequence of the plant pathogen Dickeya zeae DZ2Q, isolated from rice in Italy. Genome Announc. 2013;1(6):e00905-13.

21. Marrero G, Schneider KL, Jenkins DM, Alvarez AM. Phylogeny and classification of Dickeya based on multilocus sequence analysis. Int J Syst Evol Microbiol. 2013;63:3524-39.

22. Pritchard L, Saddler GS, Parkinson NM, Bertrand V, Elphinstone JG. Detection of phytopathogens of the genus Dickeya using a PCR primer prediction pipeline for draft bacterial genome sequences. Plant Pathol. 2012;62:587-96.

23. Pritchard L, Humphris S, Saddler GS, Elphinstone JG, Pirhonen M, Toth IK. Draft genome sequences of 17 isolates of the plant pathogenic bacterium dickeya. Genome Announc. 2013;1(6):e00978-13.

24. Zhang JX, Lin BR, Shen HF, Pu XM. Genome sequnence of the banana pathogen Dickeya zeae strain MS1, which causes bacteria soft rot. Genome Announc. 2013;1(3):e00317-3.

25. Martinez-Cisneros BA, Juarez-Lopez G, Valencia-Torres N, Duran-Peralta E, Mezzalama M. First report of bacterial stalk rot of maize caused by Dickeya zeae in Mexico. Plant Dis. 2014;98(9):1267.

26. Ramachandran K, Manaf UA, Zakaria L. Molecular characterization and pathogenicity of Erwinia spp. associated with pineapple [Ananas comosus (L. ) Merr.] and papaya (Carica papaya L.). J Plant Protection Res. 2015;55(4): 396-404.

27. Kumar A, Hunjan MS, Kaur H, Dhillon HK, Singh PP. Biochemical responses associated with resistance to bacterial stalk rot caused by Dickeya zeae in maize. J Phytopathol. 2017;165:822-32.

28. Reifschneider FJB, Lopes CA. Bacterial top and stalk rot of maize Zea mays in brazi. Plant Dis. 1982;66(6):519-20.

29. Masumi M, Izadpanah K. Occurrence of bacterial stalk rot of maize in Fars Province. Iranian J Plant Pathol. 1988;24(1-4):29-30.

30. Takeuchi T, Kodama F. Bacterial stalk rot of corn caused by Erwinia chrysanthemi pv. zeae (Sabet) Victoria, Arboleda et Muñoz occurred in Hokkaido, Japan, Annual Report of the Society of Plant Protection of North Japan; 1992. p. 42-4

31. Zheng YN. Occurrence and control of bacterial stalk rot of maize. J Anhui Agric Sci. 2006;34(10):2128-7.

32. El-Helaly AF, Abo-El-Dahab MK, El-Goorani MA, Gabr MR. Identification of Erwinia sp., causing stalk rot of maize in Egypt. Zentralbl Bakteriol Naturwiss. 1978;133(7-8):680-5.

33. Wei G, Huang YL, Huang XS. Infection way and hosts of rice foot rot bacteria. Guangxi Agric Sci. 1986;6:32-4 (in Chinese).

34. Liu QG, Zhang Q, Wei CD. Advances in Research of Rice Bacterial Foot Rot Sci Agric Sin. 2013;46(14):2923-31 (in Chinese).
35. Zhou Y, Zhai YC, Cao BH. Rice bacterial foot rot seriously happened in Rudong County, Jiangsu Province. Plant Prot. 1989;6:51 (in Chinese).

36. Yang MH. Serious rice bacterial foot rot occurred in Taining County of Fujian Province in 1999. Plant Prot Technol Ext. 2000;20(2):41 (in Chinese).

37. Li CY. Occurrence and control measures of rice bacterial foot rot in Anshun. Plant Doct. 2007;20(4):8 (in Chinese).

38. Xue NQ, Liu Y. Occurrence and control of rice bacterial foot rot. Shandong Agric Sci. 2008:3:102-3 (in Chinese).

39. Collmer A, Bauer DW. Erwinia chrysanthemi and Pesudominas syringae: plant pathogens trafficking in extracellular virulence proteins. Curr Top Microbiol Immunol. 1994;192:43-78.

40. Reverchon S, Rouanet C, Expert D, Nasser W. Charaterization of indigoidine biosynthetic genes in Erwinia chrysanthemi. Mol Microbiol. 2002;29:1407-18.

41. Franza T, Mahé B, Expert D. Erwinia chrysanthemi requires a second iron transport route dependent of the siderophore achromobactin for extracellular growth and plant infection. Mol Microbiol. 2005;55: 261-75.

42. Yap MN, Yang CH, Barak JD, Jahn CE, Charkowski AO. The Erwinia chrysanthemi type III secretion system is required for multicellular behavior. J Bacteriol. 2005;187:639-48.

43. Zhou JN, Cheng YY, Lv MF, Liao LS, Chen YF, Gu YF, Liu SY, Jiang ZD, Xiong YY, Zhang LH. The complete genome sequence of Dickeya zeae EC1 reveals substantial divergence from other Dickeya strains and species. BMC Genomics. 2015;16:571.

44. Zhou JN, Zhang HB, LV MF, Chen YF, Liao LS, Cheng YY, Liu SY, Chen SH, He F, Cui ZN, Jiang ZD, Chang CQ, Zhang LH. SlyA regulates phytotoxin production and virulence in Dickeya zeae EC1. Mol Plant Pathol. 2016;17(9): 1398-408.

45. Lv MF, Chen YF, Liao LS, Liang ZB, Shi ZR, Tang YX, Ye SX, Zhou JN, Zhang $\mathrm{LH}$. Fis is a global regulator critical for modulation of virulence factor production and pathogenicity of Dickeya zeae. Sci Rep. 2018;8(1):341.

46. Coenye T, Falsent E, Vananneyt M, Hostef B, Govant JRW, Kersters K, Vandamme P. Classification of Alcaligenes faecalis-like isolates from the environment and human clinical samples as Ralstonia gilardii sp. nov. Int. J Syst Bacteriol. 1999:49:405-13.

47. Brady C, Cleenwerck I, Venter SN, Vancanneyt M, Swings J, Coutinho TA Phylogeny and identification of Pantoea species associated with plants, humans and the natural environment based on multilocus sequence analysis (MLSA). Syst Appl Microbiol. 2008;31:447-60.

48. Tamura K, Peterson D, Peterson N, Steche G, Nei M, Kumar S. MEGA5: molecular evolutionary genetics analysis using maximum likelihood, evolutionary distance, and maximum parsimony methods. Mol Biol Evol. 2011:28:2731-9.

49. Barras F, Thurn KK, Chatterjee AK. Resolution of four pectate lyase structural genes of Erwinia chrysanthemi (EC16) and characterization of the enzymes produced in Escherichia coli. Mol Gen Genet. 1987;209:319-25.

50. Scott-Craig JS, Panaccione DG, Cervone F, Walton JD. Endopolygalacturonase is not required for pathogenicity of Cochliobolus carbonum on maize. Plant Cell. 1990;2:1191-200.

51. Chatterjee A, Cui Y, Liu Y, Dumenyo CK, Chatterjee AK. Inactivation of rsmA leads to overproduction of extracellular pectinases, cellulases, and proteases in Erwinia carotovora subsp. carotovora in the absence of the starvation/cell density-sensing signal, N-(3-oxohexanoyl)-L-homoserine lactone. Appl Environ Microbiol. 1995;61(5):1959-67.

52. Hayward AC. Biology and epidemiology of bacterial wilt caused by Pseudomonas solanacearum. Annu Rev Phytopathol. 1991;29:65-108.

53. Kao CC, Barlow E, Sequeira L. Extracellular polysaccharide is required of wildtype virulence of Pseudomonas solanacearum. J Bacteriol. 1992;174(3):1068-71.

54. Condemine G, Castillo A, Passeri F, Enard C. The PecT repressor coregulates synthesis of exopolysaccharides and virulence factors in Erwinia chrysanthemi. Mol Plant-Microbe Interact. 1992;12(1):45-52.

55. Liao LS, Cheng YY, Liu SY, Zhou JN, An SW, Lv MF, Chen YF, Gu YF, Chen $\mathrm{SH}$, Zhang LH. Production of novel antibiotics zeamines through optimizing Dickeya zeae fermentation conditions. PLoS One. 2014;9(12):e116047.

56. Stiernagle T. Maintenance of C. elegans. In: Fay D, editor. C. elegans: a practical approach. Oxford: Oxford University Press; 1999. p. 1-11.

57. Tan MW, Mahajan-Miklos S, Ausubel FM. Killing of Caenorhabditis elegans by Pseudomonas aeruginosa used to model mammalian bacterial pathogenesis. Pro Natl Acad Sci USA. 1999;96:715-20.

58. Houthoofd K, Braeckman BP, Vanfleteren JR. The hunt for the record life span in Caenorhabditis elegans. J Gerontol A-Biol Sci Med Sci. 2004;59:408-10. 
59. Chen YF, Lv MF, Liao LS, Gu YF, Liang ZB, Shi ZR, Liu SY, Zhou JN, Zhang LH. Genetic modulation of c-di-GMP turnover affects multiple virulence traits and bacterial virulence in rice pathogen Dickeya zeae. PLoS One. 2016; 11(11):e0165979.

60. Cheng YY, Liu XL, An SW, Chang CQ, Zou YQ, Huang LH, Zhong J, Liu QG, Jiang ZD, Zhou JN, Zhang LH. A nonribosomal peptide synthase containing a stand-Alone condensation domain is essential for phytotoxin zeamine biosynthesis. Mol Plant-Microbe Interact. 2013;26:1294-301.

61. Masschelein J, Mattheus W, Gao LJ, Moons P, Van Houdt R, Uytterhoeven B, Lamberigts C, Lescrinier E, Rozenski J, Herdewijn P, Aertsen A, Michiels C, Lavigne R. A PKS/NRPS/FAS hybrid gene cluster from Serratia plymuthica RVH1 encoding the biosynthesis of three broad spectrum, zeamine-related antibiotics. PLoS One. 2013;8(1):e54143.

62. Hellberg JEEU, Matilla MA, Salmond GPC. The broad-spectrum antibiotic, zeamine, kills the nematode worm Caenorhabditis elegans. Front Microbiol. 2015;6:137.

63. van der Wolf JM, Nijhuis EH, Kowalewska MJ, Saddler GS, Parkinson N, Elphinstone JG, Pritchard L, Toth IK, Lojkowska E, Potrykus M, Waleron M, de Vos P, Cleen-Werck I, Pirhonen M, Garlant L, Helias V, Pothier JF, Pflüger V, Duffy B, Tsror L, Manulis S. Dickeya solani sp. nov., a pectinolytic plant pathogenic bacterium isolated from potato (Solanum tuberosum). Int I Syst Evol Microbiol. 2014;64:768-74.

64. Liu SY, Tang YX, Wang DC, Lin NQ, Zhou JN. Identification and characterization of a new Enterobacter onion bulb decay caused by Lelliottia amnigena in China. App Micro Open Access. 2016;2:114.

65. Golanowska M, Kielar J, Łojkowska E. The effect of temperature on the phenotypic features and the maceration ability of Dickeya solani strains isolated in Finland, Israel and Poland. Eur J Plant Pathol. 2017;147(4):803-17.

66. Potrykus M, Golanowska M, Hugouvieux-Cotte-Pattat N, Lojkowska E. Regulators involved in Dickeya solani virulence, genetic conservation, and functional variability. Mol Plant-Microbe Interact. 2014;27:700-11.

67. Alič $\breve{S}$, Naglič T, Tušek-Žnidarič M, Peterka M, Ravnika M, Dreo T. Putative new species of the genus Dickeya as major soft rot pathogens in Phalaenopsis orchid production. Plant Pathol. 2017;66(8):1357-68.

68. Li P, Wang DC, Yan JL, Zhou JN, Deng YY, Jiang ZD, Cao BH, He ZF, Zhang LH. Genomic analysis of phylotype I strain EP1 of Ralstonia solanacearum species complex reveals substantial divergence from other Ralstonia solanacearum strains. Front Microbiol. 2016;7:719.

69. Deng YY, Wu J, Yin WF, Li P, Zhou JN, Chen SH, He F, Cai J. Diffusible signal factor family signals provide a fitness advantage to Xanthomonas campestris pv. campestris in interspecies competition. Environ Microbiol. 2016;18(5): 1534-45.

70. Zhou L, Wang J, Zhang LH. Modulation of bacterial Type III secretion system by a spermidine transporter dependent signaling pathway. PLoS One. 2007; 2(12):e1291

71. Li MH, Xie XL, Lin XF, Shi JX, Ding Z, Ling JF, Xi PG, Zhou JN, Leng YQ, Zhong SB, Jiang ZD. Functional characterization of the gene FoOCH1 encoding a putative 4 a-1, 6-mannosyltransferase in Fusarium oxysporum $\mathrm{f}$. sp. cubense. Fungal Genet Biol. 2014;65(4):1-13.

72. Shu CW, Zou CJ, Chen JL, Tang F, Yi RH, Zhou EX. Genetic diversity and population structure of Rhizoctonia solani AG-1 IA, the causal agent of rice sheath blight, in South China. Can J Plant Pathol. 2014;36(2):179-86.

73. Zhang SL, Liang ML, Naqvi NI, Lin CX, Qian WQ, Zhang LH, Deng YZ Phototrophy and starvation-based induction of autophagy upon removal of Gcn5-catalyzed acetylation of Atg7 in Magnaporthe oryzae. Autophagy. 2017;13:1318-30.

74. Liao LS, Zhou JN, Wang HS, He F, Liu SY, Jiang ZD, Chen SH, Zhang LH. Control of litchi downy blight by zeamines produced by Dickeya zeae. Sci Rep. 2015;5(1):1519.

75. Liu SY, Lin NQ, Chen YM, Liang ZB, Liao LS, Lv MF, Chen YF, Tang YX, He F, Chen SH, Zhou JN, Zhang LH. Biocontrol of sugarcane smut disease by interference of fungal sexual mating and hyphal growth using a bacterial isolate. Front Microbiol. 2017;8:778.

Ready to submit your research? Choose BMC and benefit from:
- fast, convenient online submission
- thorough peer review by experienced researchers in your field
- rapid publication on acceptance
- support for research data, including large and complex data types
- gold Open Access which fosters wider collaboration and increased citations
- maximum visibility for your research: over 100M website views per year
At BMC, research is always in progress.
Learn more biomedcentral.com/submissions

